Archivum, LXX (II), 2020, pp. 197-231

\title{
An Unexpected Fraternity: An Approach to Holocaust Memoirs in English Through Animal Metaphorization
}

\author{
Laura Miñano Mañero \\ UNIVERSITAT DE VALÈNCIA \\ laura.minano@uv.es
}

Recibido : $11 / 05 / 2020$
Aceptado : 01/09/2020

\begin{abstract}
:
This paper examines autobiographical texts written by Nazi concentration camp survivors to explore the authors' metaphorization of animals as a means of conveying their own suffering. The authors whose memoirs are analyzed migrated to America after the war, and significantly chose to pen their traumatic experience in English, which must have been a challenging endeavor for them as non-native speakers. Since academic discussion on the Holocaust is mainly conducted in an Anglophone framework, it is vital that we pay attention to English-language memoirs, and listen to the survivors' genuine words, rather than merely relying on translations. I suggest that animal metaphorization allows them to overcome in some way the ineffability inherent to all Holocaust memoirs. Moreover, by exploring animal images it is possible to inquire about their personal attitudes regarding other species, as authors often sympathize with -and relate to-animal suffering. My main goal is thus to decide whether this rhetorical resource points at the emergence of an interspecies empathy, based on the shared ability to feel pain and, as sentient beings, to suffer.
\end{abstract}


KEYWORDS: Human-Animal Studies (HAS), Nazi concentration camps, autobiographical literature, testimony, metaphor.

\title{
Fraternidad inesperada: un acercamiento a las memorias del Holocausto en lengua inglesa a través de la metáfora animal
}

\begin{abstract}
RESUMEN:
Este trabajo examina textos autobiográficos escritos por supervivientes de los campos de concentración nazis con el objetivo de explorar la metaforización de los animales como medio para transmitir el sufrimiento de los autores. Los autores estudiados emigraron a Estados Unidos después de la guerra y eligieron significativamente el inglés, una lengua extranjera, para relatar la experiencia traumática, una tarea indudablemente dificil. Puesto que la discusión académica sobre el Holocausto se desarrolla principalmente en un marco anglófono, es vital que prestemos atención a las memorias redactadas originalmente en inglés, y que escuchemos las palabras genuinas de los supervivientes, en vez de confiar únicamente en traducciones. Sugiero que la metáfora animal les permite superar de alguna manera la inefabilidad inherente a todas las memorias del Holocausto. Además, al explorar estas imágenes es posible indagar sobre sus actitudes personales respecto a otras especies, ya que los autores a menudo se identifican y simpatizan con el sufrimiento animal. Mi propósito es, por tanto, decidir si este recurso retórico apunta a la aparición de una empatía entre especies, basada en la capacidad compartida de sufrir.
\end{abstract}

PALABRAS CLAVE: Estudios sobre la Relación Humano-Animal (ERHA), campos de concentración nazis, literatura autobiográfica, testimonio, metáfora.

\section{Introduction}

One of the most paradigmatic works of art produced by Jewish deportees in concentration camps shows a small, yellow butterfly flying over the barbed wire, with a distant view of snowcapped mountains. Karl Bodek and Kurt Conrad Löw, prisoners of the Gurs Camp, created this watercolor painting, One Spring, in 1941. It is nowadays exhibited in the Yad Vashem Art Museum and epitomizes the legacy of Holocaust art. Why would the artists choose a butterfly to symbolize their suffering? Or, rather, why 
would they use this delicate creature to express their longing for freedom? In concentrationary literature, metaphorization of animals is also a ubiquitous, productive rhetorical resource invoked by the authors to convey their ordeal through the camps. In some way, it seems that animal images allow the authors to overcome the ineffability inherent to Holocaust memories. By exploring animal metaphors, it is possible to inquire about the authors' personal feelings regarding other species, as they often sympathize with animal suffering. This paper examines survivors' memoirs to explore whether the animal metaphor involves the emergence of an interspecies empathy, based on the shared ability to feel pain, rather than just a literary instrumentation of animals.

English was never the mother tongue of European survivors, so the authors in this corpus chose a foreign tongue to pen their ordeal, an unquestionably highly demanding task. This fact is particularly significant, and therefore it is essential to consider what it may entail. On the one hand, it may imply that, to a greater or lesser extent, they embraced the Anglo-American community that had sheltered them, and they wanted this society, rather than Europeans, to respond to their texts. On the other, since English grew during the second half of the twentieth century as a vehicular language, by choosing it they could also address a wider, international audience. Finally, perhaps it is also possible to argue that their refusing to describe such an appalling experience in their mother tongue may be triggered by a need to distance themselves from their past, as if mere linguistic dissociation could help to protect them from their trauma. In any case, the fact that they bore witness in English is enlightening for the academic community. Discussion on the Holocaust is primarily conducted in the Anglophone context; thanks to authors as the ones studied in this corpus, we can explore the actual writing of survivors, rather than solely relying on English translations, which may be more or less accomplished, but can never truly convey the authors' genuine words and thought processes. 
Before engaging in the discussion, I will delve into $\mathrm{Hu}-$ man-Animal Studies (from now on, abbreviated as HAS), a prevailing academic discipline aimed at the exploration of human nature in relation to the other species with whom we share the world. Paralleling the Holocaust to animal exploitation has been both practiced and denied by several authors: although I will present the current controversy, I will not participate in the debate. Instead of disputing whether it is fair to compare the Holocaust to animal exploitation or not, I would like to explore an alternative, constructive way of bringing together both subjects respectfully. My goal is to analyze to what extent animal metaphorization allows survivors to convey their traumatic experience, and to determine whether this aesthetic process leads to the emergence of a sort of interspecies identification and responsiveness.

Once these interrelated matters have been duly discussed, I will introduce the corpus of analysis. Then, as this paper focuses essentially on metaphors, I will examine the basic features of this rhetorical resource. The following analysis is organized in two main sections: on the one hand, I will analyze survivors' evocations of animal allegories as a means to describe the physical abuse they were subjected to in the camp. On the other, I will focus on the most symbolic representations of animals, used by both the oppressor and the oppressed. I finish this discussion by reflecting on the extremely productive nature of animal metaphorization in Holocaust survivors' texts.

\section{HAS and the Holocaust}

Survivors repeatedly denote the ineffability inherent to the experienced events, meaning that it is impossible to convey the trauma through traditional discourse and language. Their accounts, thus, show the struggle of authors who endeavor to put into words an unspeakable truth. Throughout this endeavor, animal metaphorization is a productive strategy used in an effort to overcome ineffability and convey the unique nature of 
the camps. There is a sort of identification and responsiveness between humans and other animals that justifies approaching memoirs from a HAS perspective. HAS is a prevailing interdisciplinary field that explores and critically evaluates the multifaceted and complex relationships between humans and other species, disengaging from traditional anthropocentric notions and prejudices. According to Marion Copeland (2012, 91-92), most of the disciplines aimed at the study of the relationships between animals and humans appeared in the 1980s, a decade in which the increase of social-awareness allowed the academic community to broaden their horizons to new views and angles. The initial contribution of Animal Studies was the suggestion that non-human perspectives actually existed and could provide an epistemological framework to enhance and enrich our consciousness, and therefore help us overcome the traditional medieval western belief, which assumed the existence of an impervious boundary separating humans from animals.

In this line, Literary Animal Studies suggest that arts, being the initial human response to the outside world and the other creatures with whom they share it, still hold power to blur this impermeable boundary that detaches our species from all the others, allowing us to recover earlier ideas, thus reflecting the time "when humans knew they were one among many other animals, and anthropocentrism had not yet emerged to deny that kinship" (Copeland, 2012, 91). The roots of this new approach to art, hence, encourage the reader to reread and reinterpret canonical literature so as to focus on the roles played by animals and on their symbolism. Understanding human attitudes towards animals, after all, allows us to better comprehend our own nature.

The ghastly conditions of concentration camp inmates have been several times compared to those suffered by animals subjected to human domination. Nobel Prize winner J. M. Coetzee was one of the earliest authors to establish the association. In The Lives of Animals, the narrator's mother, Elizabeth Costello, a writer, is invited to her son's university to speak about one of her in- 
terests: animals rights. She lectures on the relationship between animals and philosophers, and also on the reflection of animals in poetry. Elizabeth parallels animals' suffering to that endured by deportees, and argues that modern human treatment to animals is "an enterprise of degradation, cruelty, and killing which rivals anything that the Third Reich was capable of, indeed dwarfs it, in that ours is an enterprise without end, self-regenerating, bringing rabbits, rats, poultry, livestock ceaselessly into the world for the purpose of killing them" $(1999,21)$.

Coetzee fictionalizes the response of a Jewish attendant to the conference, who feels deeply hurt by her words, and rejects her comparison: "If Jews were treated like cattle, it does not follow that cattle are treated like Jews. The inversion insults the memory of the dead" $(1999,49)$. His words actually epitomize the bitter critique of those who are offended by the analogy, who claim that "such comparisons presuppose a sort of absolute standard which would obliterate the sort of distinctions that any practical morality requires and $[\ldots]$ would have the effect of trivializing the Nazi crimes" (Sax, 2015, 109). Animal liberationists, instead, assume their liberal-democratic right to express themselves freely, and believe that "the comparison stands to help us to reflect on the significance of how animals are treated in contemporary times" (Sztybel, 2006, 97), as both kinds of victims have undergone equivalent degradations and destructions. According to them, the analogy does not unjustly lower the dignity of Shoah sufferers, but actually allows the preserving of their memory, since "nothing in the comparison stands in the way of remembering how humans fell victim to, perpetrated, abetted, or witnessed the Holocaust" (121).

It is not the goal of this paper to defend or dispute Costello's standpoint, although one may consider her notion of animality to be rather accurate: "to thinking, cogitation, I oppose fullness, embodiedness, the sensation of being a body with limbs that have extension in space, of being alive to the world" (Coetzee, $1999,33)$. Instead, the focus is on how this embodiedness and 
animal identity is represented in the testimonial corpus, as well as on how survivors resort to their symbolism as a literary trope that allows them to communicate their experience. This, in fact, recalls American cartoonist Art Spiegelman (2003), who illustrates the concentrationary experiences of his father, a Polish survivor, through a very postmodern depiction in which Jews are represented as mice, and Germans as cats. It seems that, in effect, the images of animals hold great power and allow humans to convey a deeper truth about the existence in the camps. No wonder Max Aub, Spanish deportee and author of Manuscrito cuervo (1999), decided to convey his ordeal in the French internment camps through the eyes of a raven, a spectator who analyzes and interprets human behavior. In the same line, bringing humans and non-human animals closer, Emmanuell Lévinas brought up the myth of loyal Argos, writing a short story about a dog he encountered during his reclusion:

And then, about halfway through our long captivity, a wandering dog entered our lives. One day he came to meet this rabble as we returned under guard from work. He survived in some wild patch in the region of the camp. But we called him Bobby, an exotic name, as one does with a cherished dog. He would appear at morning assembly and was waiting for us as we returned, jumping up and down and barking in delight. For him, there was no doubt that we were men. $(1976,163)$

For Lévinas, that dog was the only being who, even though non-human, could recognize the humanity of deportees in the abyss of depersonalization. Therefore, Bobby becomes a paradigm of the fluctuating relations between humans and animals that arose in the concentrationary universe, and his image truly questions the frontier between both species. Analyzing the kinship and fraternity that manifests between different creatures within the concentration camp system, therefore, seems an interesting quest, for it may allow us to better comprehend how the 
notion of humanity is denied and enforce during Nazi domination.

HAS is strongly embedded in Anglo-American culture. At the end of the $18^{\text {th }}$ century, English philosopher Jeremy Bentham claimed that the ability to suffer, rather than the ability to reason, should determine how we treat other species. In Victorian England, in the early $19^{\text {th }}$ century, the first anti-cruelty law was introduced in Parliament (Seliner, 2019, 77). More recently, with Bentham's theory as the basis, Australian philosopher Peter Singer's groundbreaking work, Animal Liberation (1975) is considered to be one of the founding studies in animal ethics. Hence, HAS academic discussion is still nowadays primarily conducted in the Anglophone world. In this sense, opening up a new space of debate -the exploration of human-animal relations in the context of concentration camps, nourished by English literature- may be highly revealing and enlightening for the current discipline.

\section{Corpus of analysis}

The social, cultural, and linguistic profile of the survivors whose memoirs we will analyze is extremely heterogeneous, as they come from many different European regions. But all of them share the same cause of deportation: being Jewish in a region under Nazi influence. Some of them suffered deportation during their childhood or adolescence, while others were adults at the time; some belonged to the upper classes and well-off families, whereas others were of humble origins. Evidently, the experience of female and male deportees, moreover, showed divergence, as each group was kept isolated from the other. Essentially, women's memoirs tend to delve into the singularities of womanhood and the unique sufferings female deportees had to endure during their internment, usually related to motherhood, prostitution, violation, and abortion.

Livia Bitton-Jackson was born in a Jewish family from Šamorin, Czechoslovakia, in a region occupied by Hungary in 1938 and by Germany in 1944, which led to the deportation of the author 
and her mother to Auschwitz. German survivor Thomas Geve, born in 1929, was barely an adolescent when he suffered deportation. In Guns and Barbed Wire (1987), he narrates his experience as a young boy in Auschwitz, where he arrived in June 1943. Seed of Sarah (1990) chronicles the childhood of Judit Magyar Isaacson, a young Hungarian girl, genuinely interested in literature and poetry, in her home country. After German occupation in 1944, she was deported to Auschwitz with her female relatives.

Anita Lasker-Wallfisch came from a well-off German Jewish family, accommodated and integrated into German society. In 1943, Lasker-Wallfisch was deported to Auschwitz. Inherit the Truth (2000) records her survival in the Polish camp: because she was a good cellist, she became a member of the women's orchestra, so she was able to maintain a privileged position in the camp's hierarchy. Sara Tuvel Bernstein, born in 1918, came from a remote village in Romania, in the part of Transylvania that was transferred to Hungary during the war. She became a seamstress apprentice and, during the hard times before deportation, she provided economical support for her family. She was deported to Ravensbrück in the fall of 1944. Olga Lengyel was also a native of Transylvania. In 1944, she voluntarily travelled with her family to Auschwitz, deceived by Nazi lies. Five Chimneys (1995) recounts the author's passage through the death camp. Lengyel found a position in the infirmary, which she used to help fellow prisoners, and joined the clandestine resistance of the camp.

Benjamin Jacobs was an odontology student from Dobra, a Polish village. In 1943 he was deported to Auschwitz, where he worked as a dentist for the SS, and removed the golden teeth of the dead prisoners; his testimony is actually entitled The Dentist of Auschwitz (1995). Samuel Drix, born in 1912, was also a Polish Jew. Despite all the difficulties he suffered because of anti-Semitism, he got a degree in medicine. In August 1942, he was locked in the Janowska camp, which he describes in detail in Witness to Annihilation (1994), a memoir that reflects the valuable perspective of a doctor. 
All the selected authors migrated to America after the war and selected a second language, English, as a vehicle of expression to communicate their traumatic experience. The concentrationary universe needs to be understood as a multilingual and intercultural experience, as up to forty languages and nationalities could coexist within the same camp (Tryuk, 2010). Unfortunately, English-language memoirs have not been the center of attention of the academic community yet; they remain outside of the Holocaust literary canon, which has mainly focused on a group of celebrated authors, considered to be prolific and skilled in literature. For instance, distinguished survivors such as Primo Levi or Imre Kertész have become eminent symbols in Italian and Hungarian literature studies, respectively. Their works have been translated into many other languages, and therefore have had great impact on the international research community. Nonetheless, there is a vast corpus of other survivors' memoirs that has been overlooked, as these texts may have been considered of less literary value. Since English was never the mother tongue of European survivors, English-language memoirs may lack stylistic or rhetorical perfection. Moreover, these survivors never became prolific, professional authors, or had any previous writing experience: they only wrote that very one time, to bear witness. Their texts, however, stand out for their directness, plainness, simplicity, and straightforwardness; the authors' commitment to the truth and drive to become the voice of the unspoken victims engenders extremely expressive, sincere writing.

Choosing a second language to pen such an ordeal must have been a very challenging endeavor. In fact, in every written English memoir, survivors have retained some words of the languages that were essential in the concentrationary system, such as Polish, Yiddish or German, so as to convey to the reader the communicative void and linguistic chaos inherent to the camp society, as well as the ineffability of the experience. When they recall their childhood and existence as free individuals, they 
usually summon words and idiomatic expressions of their native languages, so it is possible to understand how demanding it must have been to communicate such a profound experience through a foreign language. The fact that, in spite of these difficulties, they chose English to pen their experience is definitely significant. As current academic discussion about the Holocaust is mainly being conducted in the Anglophone world, I suggest that we pay more attention to English-language testimonies, rather than solely rely on translated versions of celebrated authors. Since it is impossible to fully express and comprehend the reality of the Lager as outsiders, we can only hope to get closer by listening to the original, actual words of the witness. Because these authors struggle to describe their ordeal in a second language, it is worthwhile to explore their writing. Animal metaphorization in concentrationary literature is a highly intimate, expressive, and multifaceted trope, and so I claim that, only by recognizing it in the original witness's words, can we hope for a deeper understanding.

Thus, by exploring their allegories we can inquire about the personal attitudes of the authors regarding other species. Metaphorization, the faculty of conceptualizing one entity in terms of another, is considered an essential characteristic of human cognition that has progressed with the development of language (Robin \& Long, 2011, 53). It is a process that "occurs in and through the connecting of two elements that are not assumed to be linked conceptually. In this process, aspects of the 'vehicle' domain are mapped onto corresponding aspects of the 'tenor' domain" (Webber, 2011, 8); the two entities establish a syntactic bidirectional relationship, in the constitution of which something new surfaces. The result of such figuration is emotionally evocative, and this accounts for the potential impact of a metaphoric association, which "is the core and evocation of a narrative argument -the means, in other words- by which the author seeks, in a particular context, to persuade a particular audience of a particular point" $(2011,12)$. 
Following Webber, metaphor can be an exceptionally suitable medium for ethical behavior through and in language because of its structural duplicity, -that is, its ability to bring two entities together through a connection that imaginarily and momentarily conceals their differences, while simultaneously recognizes the existence of those very differences- because when we face moral misgivings we deal "with an acknowledgement of a common humanity within which estrangements and particularities are present; with the necessity of acknowledging also and particularly the presence of those estrangements; and with metaphor as a structurally well-suited means for calling to mind that double structure" $(2011,22)$. Robin and Long also defend the great significance of metaphor, a resource that, according to them, allows people to explore their kinship with nature, since "humans use animal metaphors to frame their ongoing relationship with the environment and their place in an evolutionary continuum $(2011,62)$.

Their approach stems from evolutionary sciences, the fundamental idea being that humans, as "primates that share physical, behavioral, and neural machinery with other primate species", create animal metaphors "in order to cognitively model and represent other agents, including other humans, in our ongoing struggle for existence in a rapidly changing environment" (2011, 52). Paradoxically, this resource allows humans to conceptualize themselves as non-animals and represent themselves often in opposition to the other species: according to the authors, this differentiating and fictitious construct then becomes the pretext humans invoke to disrespect nature. In the following analysis, not only will we explore the use of the animal metaphor as a way of discriminating humans from animals, but also as a means of fraternizing with them and their suffering.

\section{Animals and their Symbolization}

\subsection{Treatment}

The journey to the camps is a turning point in the victim's experience, often being compared by survivors to the brutal 
treatment farm animals receive during their transportation. As Olga Lengyel $(1995,15)$ recalls, "we were driven like sheep and compelled to climb into an empty cattle car. [...] Ninety-six persons had been thrust into our car, including many children who were squeezed in among the luggage". In 1996, Marjorie Spiegel already established the comparison between the hellish Middle Passage transport by cargo to the New World and the brutality of cattle boats, both embodying the maximum expression of oppression (52-54). The initiation ceremony, once the prisoners arrived at the camps, was intended to dehumanize them, so that they turned into a mass of interchangeable, manipulable beings. The ritual involved dispossessing the victims of every material and spiritual bond with their pre-concentrationary existence as free individuals. Female survivors often emphasize the loss of gender differentiation associated to the ceremony (Magyar-Isaacson, 1990, 67), their bare scalps embodying a milestone in this transformation: "It made me feel totally naked, utterly vulnerable and reduced to a complete nobody" (Lasker-Wallfisch, 2000, 72). Bitton-Jackson describes in vivid detail the overall result of this affliction:

The shaving of hair has a startling effect. The absence of hair transforms individual women into like bodies. Indistinguishable. Age melts away. Other personal differences melt away. Facial expressions disappear. In their place, a blank, senseless stare emerges on the thousand faces of one naked, unappealing body. In a matter of minutes even the physical aspect of our numbers seem reduced. We become a monolithic mass. Inconsequential. Shorn heads, nude body, faceless faces. $(1997,77)$

According to the Nazi species-ranking criteria that applied in the concentrationary system, deportees had to be, in the first place, dispossessed of any trait that revealed their human nature. Following their speciesist, supremacist believes, dehumanizing the victims was the initial step towards animalization: once hu- 
manity had been denied, then it was possible to place deportees in a lower classification, which ranked non-human animals, as I will argue in the following pages. The initiation ceremony, a turning point in this process, recalls industrialized farming in several ways. Firstly, prisoners were transported to remote, isolated camps, where it was absolutely forbidden for any unwanted civilian to enter. Spiegel, drawing a comparison between secluded slave plantations and slaughterhouses, claimed that "machinery of oppression is surrounded by the maintenance and perpetuation of the secrecy" $(1996,79)$.

Secondly, the degradations prisoners endured during the initiation ritual, aimed at destroying any differentiation or individuality, also reflects the processes animals destined for consumption go through. Modern, industrialized farming implements very similar procedures to prevent any moral qualm to arise: by treating farm animals as an inconsequential mass, denying their possession of any form of individuality, it is possible for humans to give these creatures a lower status than other animals. In our Western civilization, for instance, domestic dog owners feel their pets to be somehow unique, irreplaceable, and therefore worth our affection and caring. In contrast, other not-so-different animals, those destined for consumption, are denied the possibility of showing or possessing any individuality. Therefore, these are apt for human consumption. This speciesist belief is analogous to the one that was implemented in the camps. That is, only by denying deportees personality and distinctiveness was it possible to keep the system running smoothly. Dehumanization, consequently, mirrors the animal experience at a moral and psychological level.

Both the notion of facelessness and the idea of namelessness, so frequently invoked by the survivors in their recollections of the initiation ritual, allow us to draw an analogy between the treatment of prisoners and animal suffering. It is evident that Nazis voluntarily sought to degrade victims so that they would feel their turning into Unmensch (Jacobs, 1995, 164), 'non-human 
entities', subjugated by the perpetrator. In the autobiographical accounts, the conditions victims endure during deportation often associate both kinds of beings, either literally or metaphorically. Literal identification, for instance, could happen through explicit signs, hanged on the barrack's walls:

Barrack 26 was a vast hangar of rough boards. On the door a metal plaque gave the number of horses the building would shelter. 'Mangy animals are to be separated immediately,' it read. How fortunate the horses had been! Nobody ever bothered to take any precautions on behalf of the human beings who were kept there. (Lengyel, 1995, 36)

These previous lines by Lengyel seem relevant for research on animal symbolism in two ways: on the one hand, they prove that there was a material relation between deportees and animals, as Nazis herded their victims together in spaces that had actually been conceived for the cattle, where they received an even worse treatment. On the other hand, Lengyel's words evidence the oppressor's extreme sense of speciesism, as victims were not degraded to the status of a domestic animal, but actually to an even lower category. Survivors frequently summon images of the guard dogs that accompanied SS officials in the camp, trained to viciously attack men in striped clothing on command. These German Shepherds looked clean and healthy, were extremely well fed, and were provided with comfortable shelter. Each official was constantly escorted by his or her dog; according to the testimonies, Nazi guards even played with them and showed affection to them (Lasker-Wallfisch, 2000, 33; Jacobs, 1995, 94). It is obvious that these German purebred hounds were considered, according to Nazi species-ranking criteria, to be closer to humans than prisoners themselves.

The animal metaphor also appears in statements regarding vivisection: Magyar-Isaacson uses the term "guinea pig" (1990, 116) to refer to the victims of Nazi experimentation. Olga Lengyel 
$(1995,185)$, who worked as a nurse in the camp infirmary, alludes to these creatures as well. To critically analyze the significance of this metaphor, and to go beyond this image, it is essential to highlight who exactly uses it in the concentrationary universe. Memoirs do not record Nazis researchers or officials pronouncing these words whatsoever; instead, it is an allegoric association created by the fellow prisoners as a response to the brutally unfair system. When Olga Lengyel, a trained nurse, brings up the comparison, she speaks of these animals as creatures to be taken care of; she ironically highlights the word 'scientific' to repress Nazi procedures. Therefore, the conceptual and emotional link that allows guinea pigs to be the vehicle to deportees is based on a shared empathy for both species, suffering parallel ordeals. Lengyel does not explicitly make a statement against animal vivisection, but she does implicitly acknowledge animals' ability to suffer, a premise that would, in time, become the essential anti-speciesist basis of the animal liberation movement.

The humiliations inmates endured during their endless toil were also very similar to those suffered by exploited animals: "Prisoners were driven with whips, im Laufschritt -that is, running- through the middle of the streets, while SS men and Askaris surrounded us shouting, 'Schneller, schneller'" (Drix, 1994, 96). Commanding prisoners through a violent, foreign language, which they are unable to understand, reflects general human interaction with working animals. The Nazi executioner is conceptually, linguistically, and metaphorically turning prisoners into beasts of burden. According to their speciesist worldview, sumpter animals and prisoners deserve the same treatment. Through these pages, I am trying to determine which status it is that deportees deserved according to Nazi species-ranking criteria. The fact that stands out, however, is that this status is never fixed and unchanging. Frontiers seem to be rather blurry, as Nazis paralleled prisoners to different species in diverse situations. This only shows Nazis' delusional and exacerbated supremacist mindset: only Arian, German, politically tame individuals occupied the 
highest position. All the rest of human and non-human animals were amalgamated in an arbitrary, voluble categorization.

Finally, authors tend to use the explicit slaughterhouse allegory to describe the genocide of their people: "Janowska was a slaughterhouse. [...] Like a voracious beast this slaughterhouse incessantly devoured enormous numbers of victims everyday" (Drix, 1994, 49). Is the concentration camp-slaughterhouse metaphor merely a handy visual and conceptual association? Or, on the contrary, does it also convey an emotional burden, which accounts for a sort of interspecies responsiveness and empathy, and implies the censoring of certain human practices? As Olga Lengyel witnessed a death selection being carried out in Auschwitz, she drew an expressive, sensitive comparison: "This spectacle was both tragic and humiliating. Humiliating not only for the poor sacrifices, but for all humanity. For these destitute souls now being driven to the slaughterhouses were human beings -like you and me" $(1995,52)$. The direct address to the reader is a powerful trope, establishing a straightforward conversational link between author and reader, which asks the reader to engage honestly in the debate and to be responsive. This trope reveals the author's commitment to the statement made. Simultaneously, Lengyel's juxtaposition of 'destitute souls' and 'slaughterhouses' seems to be highly meaningful: Could a destitute soul taken to the slaughterhouse be anything but human? The theme-rheme structure of her words suggests her to be, at the very least, ambiguous and uncertain about it. Her lines engender a figurative, metaphorical space for reflection about inter-species frontiers and limits.

All the previous excerpts from the author's testimonies reflect the comparable degradations inmates and animals suffered, as well as the existence of an explicit or implicit connection made by survivors regarding both groups of beings. Italian survivor and writer Primo Levi $(1989,63)$ coined the expression grey zone to state one of the most significant accomplishments of the Nazi guards: the creation of an obscure ethical dimension in which 
the border between perpetrator and victim fades away. Prisoners who succumbed to the grey zone did anything to survive, including hurting fellow inmates, and ended up accepting the oppressor's moral standards. National Socialism exerted a frightful power of corruption that was hard to escape. Thus, it is essential to determine whether this singular struggle for existence is also communicated through the animal metaphor in Holocaust literature.

Indeed, the animal allegory is also useful to portray the struggle for survival within the crowded blocks: "The block seemed a den of wild animals, beasts that howled, robbed and kill. In the dark when they had to relieve themselves they used their eating bowls. By daylight they stared at each other with eyes of hate and suspicion" (Geve, 1987, 174). Thomas Geve also relies on the animal image to describe an extremely dreadful episode that occurred in the camp, when a starved prisoner attacked him to steal from him: "the cruel ruthless teeth buried in my lean flesh were those of a madman: a human beast in search of loot, a prying animal" $(1987,165)$. Therefore, animal allegories are used in survivors' accounts to illustrate the prisoners' surrender to the grey zone, their struggle for survival, and some of the most horrible features of the uncivilized camp society. The Nazi oppressors treated their victims as animals, and forced them to act like them in many ways.

Some inmates became violent towards each other as a result of being confined in an impoverished environment, where they were unable to fulfill any of their physical, psychological, or social needs. At this point, it seems only fair to extrapolate this situation and reflect on other forms of current non-human animal oppression. It is worthwhile considering whether unfair human treatment of animals leads to their development or enhancement of predatory instincts. In this respect, Anderson et al. (2016) have studied orca behavior associated with oceanarium confinement. Cetacean brains are consistent with high-level cognitive abilities, such as attention, problem-solving skills, intuition, judgment, 
and social awareness. These scientists have conducted research on orcas' response to human abuse, and have concluded that attacks on humans are thoroughly caused by it. Therefore, they believe that "the confinement of orcas within aquaria, and their use in entertainment programs, is morally indefensible, given their high intelligence, complex behaviors, and the apparent adverse effects on orcas of such confinement and use" $(2016,49)$. Confinement and exploitation prove to be fatal not only to humans, but also to other species: it enhances predatory and violent instincts. Human response to imprisonment and extreme coercion, as the analyzed memoirs show, parallels non-human animals' experience, especially orcas', because both species share tremendous similarities.

From a psychological perspective, another equivalence can also be established between humans' and other animals' response to abuse. According to Seligman (1971), learned helplessness is a phenomenon observed in different species as an emotional reaction against coercive environments. Human and non-human animals who have been externally conditioned to expect suffering without a possibility to escape it finally surrender and stop trying to avoid the pain at all. Concentration camp memoirs often evoke the image of those extremely exhausted, famished prisoners who give up any hope and become utterly helpless. According to German historian Eugen Kogon (1996, 342), these individuals were commonly referred to as 'camels' in Neuengamme concentration camp; and 'donkeys' in Majdanek. These epithets reveal a conceptual connection, made explicit through language, linking animal and human learned helplessness. Kogon acknowledges the fact that "common to all these designations is the clearly negative connotation. These are scornful, mocking labels that express rejection and disdain". These completely powerless individuals were badly treated by the other prisoners (maybe because by witnessing their dreadful transformation, they feared their own inescapable fate). Unfortunately, deciphering the significance of the specific animal images mentioned by Kogon exceeds the 
purpose of this paper, as they do not manifest themselves in our English-language corpus of analysis. However, it is worthwhile to at least point at it as a potential HAS research area for future investigations.

\subsection{Symbolism and Interpellation}

In spite of the fierce struggle for survival, many of the concentration camp inmates -and definitely all of the authors considered in this work- resisted moral corruption, no matter how terrible their conditions were. In the following section, in fact, I will begin by analyzing how the animal metaphor is also used to convey the most righteous human features, epitomized in the bird image. The authors evoke the image of the caged bird to symbolize their lost freedom, therefore fraternizing with the lack of liberty of non-human species and embracing their suffering for being confined by an oppressive entity. For instance, Livia Bitton-Jackson uses the bird metaphor to describe the feelings of her aunt Serena, who "has changed since we left home. [...] Now she is silent. Silent and sad, and withdrawn, like a singing bird snatched from her nest and locked up in a cage. [...] As if she left her soul in her nest" $(1997,47)$. Tuvel Bernstein mourns her deceased relative by establishing an analogous comparison: "Oh, if only Tamara did not sing! Let her not have sung. But can a bird not sing? Even in prison it swells into song" $(1997,242)$. As in the previous quote, the simile of the caged animal becomes a means to represent the barbed wires of the camp, but Bernstein's lines also raise the subject of the victim's voicelessness. In other words, even though Tamara tried to keep her voice and sing, she finally perished in the camp, falling forever into silence. But whereas the author is using the metaphor to express her grief for a loved one, she seems to be simultaneously suggesting something hopeful, noble, and reassuring of all imprisoned beings: their natural impulse to fight for their voice, regardless of how awful their conditions might be. However, the concentrationary universe finally silenced both of them: "She had a voice so 
beautiful that I used to pretend I was in a great theater when she sang to us in the kitchen after supper, but she would not sing in a camp" (Tuvel Bernstein, 1997, 242); "She has stopped singing. I used to love to listen to her voice -a soft, melodious, warm voice" (Bitton-Jackson, 1997, 242).

Bradshaw et al. (2009) have argued that non-human animals may suffer from Complex Post-Traumatic Stress Disorder. After examining the symptoms of many confined parrots through the lens of Complex PTSD, they have reached the conclusion that, in fact, these are essentially similar to those manifested in concentration camp survivors and POW. The symptoms include alterations in emotional regulation and in consciousness. This disorder, in caged parrots, also affects singing: either they just give it up, or they merely sing to claim attention. Hence, the metaphor evoked in the memoirs suggesting the image of a hurting, confined bird, no longer able to sing, responds to the genuine experience of real animals.

The metaphor of the free bird, as opposed to that of the caged animal, conveys the hope of the authors for a brighter future and their trust in human nature. For example, Lasker-Wallfisch summons it to describe the honest nature of a fellow deportee, who "remained a free bird in her feelings and her faith like a naïve child" (2000, 154). Judit Magyar-Isaacson also appeals to the image of this animal, comparing it to her most beloved treasure in the camp, a blue kerchief she used to cover her head: "it was nothing but a swatch of torn mattress cover, but I had gambled my life for it and won. I stood at Zähl Appell on that fateful afternoon, with my bald head capped in azure -as if Maeterlinck's bluebird of happiness had perched on my shorn crown" (1990, 80). The Blue Bird is a play for children by Belgian poet and playwright Maeterlinck, premiered in 1908. Two kids look for the blue bird of happiness to help a sick girl walk again. In their sleep, they travel to a dreamland, where animals and plants can speak, aided by a fairy. Magyar-Isaacson refers to that blue bird, an epitome of happiness, in order to express how grateful she 
was for possessing the kerchief. The piece of cloth allowed her to distinguish herself from the mass and to cover her shorn head, a symbol of oppression. Therefore, it was a precious belonging used to recover her individuality and claim her human identity. The comparison, established by the similar color of both entities, shows her respect for the vehicle of the metaphor.

Actually, it is not the only episode in which this survivor evokes a literary representation of birds. While doing slave work for the SS in the frozen countryside, she saw one of these creatures: "A small bird was chirping on a pine branch, reminding me of Lörincz Szabó's lilting poem, Nyitnikék, about a tiny bird's endurance and faith". She goes on to quote some verses of the Hungarian poet that encourage her to endure the ordeal: "As winter grows meaner and leaner, its song of hope thrills clearer and keener" $(1990,108)$. Benjamin Jacobs also recalls the arousal of deep emotions when seeing birds in the sky while he was working for the Nazis: "Birds flew in formation in and out of our 'fortress' with ease. I wish that I could share their freedom" $(1995,13)$. He experiences a sensation of longing and, at the same time, he feels attached to them. The bird image allows him to understand his inner self and convey his worldview to the readers. In fact, Jacobs alludes to these animals earlier in his text as well, to describe the gloomy, miserable atmosphere of his hometown on the day all Jews were deported:

On the morning of May 4, 1941, three ancient trucks labored against a Polish country road, carrying 167 Jews from Dobra, a village in the Warthegau region of Poland, to a destination known only to their captors. It was spring, but the fields, which were full of colorful budding flowers, seemed lifeless on that gloomy morning. The songbirds, whose melodies usually filled the country air in May, were strangely quiet. $(1995,83)$

This quote proves essential for HAS research connected to the concentrationary experience because the author is humaniz- 
ing nature, as a rhetorical and symbolic trope, and opposing this empathetic, compassionate nature to the madness and barbarism of the Nazi perpetrator. Jacobs is implicitly attributing human qualities -that is, anthropomorphizing- to those non-human beings, such as flowers and birds, which express their condemnation through silence. Significantly, the image of a quiet bird is evoked once again, although this time it does not involve a response to abuse and confinement, but rather a conscious expression of sympathy towards other oppressed beings. These lines insinuate birds to be more human than cruel Nazis, and therefore suggest the idea of an inter-species identity that, instead of originating in biological likeness, stems from the shared ability to sympathize with other hurting creatures and, therefore, to feel pain themselves.

Insinuating that birds may actually be more human than those human beings who have given up all sense of morality is therefore a severe statement which challenges the conventional anthropocentric and speciesist limits separating humankind from the rest of species on the foundations of reason. The images of the caged and free bird, constant motifs in literature, acquire in concentrationary memoirs exemplary significance because they do not only involve traditional metaphorical representations, but they also engage in a much deeper, existential debate about the essence of humankind. The concentration camp experience is a unique milestone and a philosophical turning point in Western civilization, responsible for countless new discussions and conceptions about humanity, ranging from Arendt's 'banality of evil' theory (1963), to Adorno's statement about writing poetry after Auschwitz being a barbaric endeavor (1963). Hence, I suggest that the concentrationary universe, because of its unique nature, also provides a singular framework for HAS. By delving into it through the lens of HAS, we may be able to explore the very complex contemporary relations between humans and other species.

Apart from the bird metaphor, survivors also appeal to other animals in order to convey their suffering. For instance, Mag- 
yar-Isaacson uses the analogy to express her extreme starvation: "hunger became painful and scary [...]. I complained to mother: 'I want to howl from hunger like a wolf"' $(1990,117)$. The deportee's feeling of having become a predator's prey also leads survivors to sympathize with hunted creatures: "The very same day two of our brigadiers were beaten by the SS men, attached to two barriers like animals to be roasted, and left hanging for several hours" (Drix, 1994, 64); "Here, one could see SS men beating prisoners with whips until they bled; there, misfortunates hanging from wooden rods by hand and foot, like animals brought home from the hunt" (Drix, 1994, 69). In both scenes, the author suggests a comparison between, on the one hand, huntsmen and SS guards and, on the other, hunted animals and inmates in the camps. Not only do these excerpts vividly portray the brutal treatment suffered by prisoners, but they also convey the author's compassion for hunted creatures, as well as his own identification with them.

Apart from the brutal physical treatment deportees receive, the Nazi perpetrator implements a deliberately dehumanizing communication system with their victims, aimed at annihilating any vestige of resilience and endurance, by using psychological domination. This form of subjugation seems closely related to human interaction with oppressed animals in other contexts. In 1995, Alain Parrau devoted Écrire les camps to the exploration of concentrationary literature. The author suggests the corruption of language as a central element that is reflected in survivors' memoirs with persistence. Totalitarian systems, he claims, need to violate language so as to achieve their goal of turning victims into a manipulable mass of depersonalized subjects, and this process of dehumanization crystallizes clearly in the relationship established between the totalitarian executioner and the inmates. In fact, communication between the two antagonistic groups is corrupted to the point that the oppressor addresses their victims without expecting any response, but only the execution of an order. This, according to Parrau, recalls humans' way of interacting with animals (189). 
Indeed, survivors' accounts insistently reflect the corruption of human language. Firstly, several different languages coexisted in the camps, as authors recall in their memoirs: "Birkenau became a real 'Tower of Babel', with every kind of language spoken" (Lengyel, 1995, 141). As a result, many of these inmates were not native German speakers and did not speak the language of power. The inability to understand each other and to follow the executioner's orders creates a chaotic, confusing atmosphere that can easily be linked to human-animal interaction, as both groups of victims -deportees and animals in general- are generally unable to comprehend the master's language. Regarding this situation, the reaction of the oppressor in the camps seems very similar to human behavior with animals in the outer world. For instance, Tuvel-Bernstein recalls the prisoners in charge of her block, one of whom was German and the other Polish: "If you understood neither German nor Polish your life was filled with terror as you tried to guess what you were being ordered to do before a club came down on your head for not obeying fast enough" (211-212). Her lines prove that physical abuse becomes the universal camp language used to transmit every instruction, pretty much like wild, free animals have been broken by men throughout history.

Language has traditionally been considered as the fundamental difference between humans and the rest of species. In the Aristotelian tradition, real 'language' is an exclusively human characteristic, based on the ability of producing independent and active utterances. Other creatures that may show sophisticated forms of communication, such as birds, do not fall under the same category as humans, the only species capable of genuine language, 'logos'. Herein lies the difference between reason and instinct, separating humankind from the rest of animals (Fögen, 2014). Two millennia after Aristotle and ancient reflections on animal communication, Descartes' philosophy suggested the idea that non-human animal behavior was merely explained by reflex, therefore conceiving animals as emotionless, mechanical 
beings driven by instincts, as opposed to humans, who are capable of rational thought and understanding (Waldau, 2013, 144). More recently, Chomsky's Cartesian Linguistics revivified Descartes' arguments about language as a unique species-specific ability $(2009,59)$.

Hence, the language barrier has traditionally strengthened speciesist beliefs separating humankind from the rest of animals. Fortunately, contemporary insights on animal cognition reflect the twenty-first century's change in focus from conventional anthropocentrism towards a more comprehensive study of species-specific semiotic skills, highlighting the significance of observing each species in the wild, instead of in captivity. This epistemological shift allows us to reexamine human relationships with other creatures and to challenge established ideas regarding their semiotic and cognitive profiles, as well as the fact that these differences justify human superiority (Augusty, 2018). Taking the concentrationary universe as a background to interweave HAS and sociolinguistic research, the idea that the executioner's corruption of language plays an essential role in the victim's dehumanization process is self-evident. On the one hand, the oppressing group of humans, the Nazis, deliberately refuses their innate ability to communicate resourcefully with other members of the same species. Of course, this natural ability does not only refer to a shared verbal language, but to all other semiotic systems that account for social interaction at a pragmatic level. Hence, the Nazi executioner denies effective communication to all inmates -both to German speakers and to speakers of other languages- and, by doing so, they mirror their speciesist beliefs on other human beings.

On the other hand, linguistic oppression affected particularly all those prisoners who were not able to speak any German, the only language considered to be human and civilized by the totalitarian system. Alain Parrau exposed the paradox inherent to this supremacist belief regarding language: amidst the linguistic chaos in the Lager, those inmates who were fluent in the lan- 
guage of power puzzled, to a certain degree, the Nazi minds, as they seemed to retain some humanity $(1995,192)$. For instance, German survivor Thomas Geve $(1987,96)$ recalls an episode in Auschwitz in which a Nazi official became astonished by his command of language and, from that moment, acquired a very condescending, but more responsive, attitude towards him. This proves how incoherent and meaningless Nazi beliefs were. The extrapolation of these considerations about the concentrationary world to a broader, more universal context, may lead to the conclusion that the speciesist theory of an impenetrable language barrier is nothing but a biased and supremacist construct, which, instead of reflecting real inter-species divergences, is only motivated by certain ideological and political notions.

Personal interpellation also showed the oppressor's determination to destroy the victim's human essence, by comparing them to animals. Livia Bitton-Jackson recalls some of the common names prisoners were referred to as, which reveal Nazi speciesism: “The epithet 'blöde Lumpen,' idiotic whores, is now degraded to 'blöde Schweine', idiotic swine. More despicable. And it is upgraded only occasionally to 'blöde Hunde', idiotic dogs. Easier to handle" $(1997,78)$. According to this author, female prisoners had to endure, apart from all other insults, classical patriarchal verbal abuse regarding prostitution. Sexual slur also seems to be closely connected to notions of purity and cleanness, which are in turn associated to animality. Gender studies as a field has already focused much attention on the Holocaust (Baumel, 1998; Petö et al., 2015; Sanfilippo, 2016). It would be interesting, nonetheless, for scholars to pursue their research combining such field with HAS, especially given the extent to which feminism and Animal Studies have joined forces in recent academic work.

The massive gassing of prisoners was conceived as a mere extermination of bugs. In this sense, Anita Lasker-Wallfisch remembers the expression commonly used by the oppressor: "the thought of being put to death like vermin was too much to bear" 
(2000, 70). In Imperfect Creatures (2016), Lucinda Cole explores the construct of vermin from a HAS theoretical perspective, focusing on early modern canonical English literature. She studies the unstable and blurry identity of vermin and parasites, considering them to be significant agents in the shaping of the human world and society. Throughout history, humans have classified certain beings as threatening creatures that needed to be exterminated because they menaced human sovereignty in different ways, mostly related to public health and hygiene. Cole states that the verminous discourse, originally human's fearful response to nature, evolved progressively into a social doctrine. Eventually, the notion of vermin not only referred to parasites, but also to any idea, reality or individual threatening the health of the hegemonic system. This was, precisely, the extrapolation made by National Socialism accounting for their intention of mass murder: behind Nazi genocide of the Jewish and Gypsy people underlies the same idea of species cleansing associated traditionally to vermin.

However, animalizing the other is not only a method adopted by the executioner so as to distance themselves from their victims. Instead, it seems to be a bidirectional strategy: deportees also animalize their captors so as to express their cruelty, their oddness, and their inability to communicate with prisoners. Olga Lengyel provides a vivid example in this sense: "S.S. Women were strange silhouettes in their large black rain capes. They looked like vultures waiting for their prey" $(1995,47)$. In these previous lines, Nazi guards are depicted as scavenging birds of prey, circling overhead as prisoners struggle for survival. In the eyes of inmates, S.S. women turn into mere silhouettes, rather than human entities, therefore losing their individual uniqueness and becoming an inconsequential, shapeless mass. Anita Lasker-Wallfisch evokes an analogous memory regarding her arrival at Auschwitz: "When I try to recall my first impressions of Auschwitz, what comes to mind are black figures in capes" $(2000,71)$. These quotes transform the executioner into a vague, dark figure or silhouette: a shadow rather than an autonomous individual. 
Both the notion of animality and the image of an imprecise silhouette are expressive means to refer to the concept of otherness. Perceiving someone as the other implies, on the one hand, believing in the existence of a stark dichotomy separating two non-reconcilable entities. From a traditional anthropocentric perspective, the ultimate legitimate frontier has always been the separation between humans and animals. On the other hand, the perception of otherness also entails a component of blurriness and vagueness, qualities that seem intrinsic to the notion of silhouette, as it is conceptualized in the memoirs. The other has to be determined by certain specific differentiating traits made up by the oppressive system. But, simultaneously, this differentiation also needs ambiguity and indetermination, since otherwise the lies of the hegemonic group would be thoroughly exposed. Both deportees and Nazi officials turn to the animal metaphor to disengage themselves from the other. However, before drawing any conclusion as for what this bidirectional animalization implies regarding each agent's understanding of animality as otherness, it is essential to explore a few more examples.

For instance, Livia Bitton-Jackson uses the animal metaphor in order to detach the oppressor from the victims: "The SS don't look human. Their faces aren't faces, they are grim masks. And their voices are angry barks" $(1997,68)$. Hence, just like Nazis dehumanized their victims to fulfill their purpose, deportees employed their oppressor's strategy against them, therefore claiming their personal agency and embodying an act of resistance against the totalitarian system. In this sense, authors use several verbs associated with animal sounds to illustrate the tone of their guards. These verbs are well documented in our corpus: it seems that, instead of talking, the oppressors "snarl" (Magyar-Isaacson, 1990, 116), "bellow" (Geve, 1987, 131), "growl” (Geve, 1987, 56), "roar" (Magyar-Isaacson, 1990, 78), and "howl" (Jacobs, 1995, 177). These verbs strengthen the distinction between executioner and victim, and highlight the inability of the former to communicate, while simultaneously hinting at the social heterogeneity 
of the camp society and the powerlessness of all those deportees who could not understand the language of power.

Taszak $(2009,3)$ has provided a highly explanatory description of the notion of otherness: "Opposing Us, the Self, and Them, the Other, is to choose a criterion that allows humanity to be divided into two groups: one that embodies the norm and another that is defined by its faults, devalued and susceptible to discrimination". This stigmatization becomes the legitimate criterion justifying, to the oppressing group, the domination or extermination of the others, who are downgraded to the margin of humanity. The construct of otherness, therefore, classifies individuals according to extremely asymmetric power relations. The establishment of the classifying criteria may be of a political or social nature, but it is also worth emphasizing that "the power at stake is discursive: it depends on the ability of a discourse to impose its categories".

The idea of discourse being a core element in the creation of the otherness construct proves vital for this paper, since I have sought to analyze how rhetorical tropes reflect human-animal identification and disidentification through language. When Nazi officials turn prisoners into the stigmatized other, by means of the animal metaphor, they engage in an extremely speciesist attitude. Accordingly, the metaphor is aimed at upholding their unique racial superiority, through downgrading both animals and prisoners. The metaphor is highly political, as it justifies and endorses their totalitarian system. However, deportees' perception of the other, though also conveyed through the animal image, differs significantly from the executioners' perspective. By describing their captors as animals, survivors particularly underline the communicative emptiness determining the oppressor-oppressed relationships in the Lager. Thus, in these cases otherness and animality are connected on a discursive basis: rather than looking down on the animals they evoke, survivors condemn Nazis for failing to communicate with the members of their own species, as all beings are naturally able to do. 


\section{Conclusions and Discussion}

Since the concentrationary experience represents one of the philosophical, historical, and sociological milestones in the development of Western civilization, I suggest it to be an appropriate background to conduct research on HAS as well, because of this universal significance. In Holocaust testimonies, animal images prove to be an extremely productive and multifaceted resource: they become a rich, prolific rhetorical trope that accounts for the intense expressivity of the survivor's text. Instead of arguing whether it is fair to compare the Holocaust to animal treatment or not, we could explore alternative, constructive ways of bringing together both subjects respectfully. Undoubtedly, concentrationary literature offers us a vast, suitable setting to investigate human-animal interaction and shine light on interspecies relationships. Focusing on the animal metaphor, it is essential to determine whether survivors use it only because of its traditional symbolic nature -and thus, it is merely an instrumentalization of animals- or if, instead, a real inter-species empathy and sense of responsiveness underlies this trope.

In Holocaust memoirs, authors use the notion of animality in two extremely opposed ways: on the other hand, survivors turn their oppressors into fierce, uncivilized creatures to convey their most ruthless, impulsive nature. As we have witnessed, the idea of brutality embodied in the animal metaphor is not only suitable to represent the Nazi perpetrator, but also all those prisoners who, after succumbing into the grey zone, march against their fellow inmates in order to subsist in the camps. Characterizing evil humans in terms of fierce, brutal animals is a way of detaching oneself from the enemy. In these cases, the rhetorical trope is merely metaphorical; it is purely a reification of animals and proves no empathy or identification with them. However, this fact seems also significant for HAS: it invites us to consider to what extent this objectifying metaphor has been a constant motif in our societies and literature, and what exactly it conveys about traditional human perspectives on animality. Describing oppressive oppo- 
nents through animal images evokes conventional Western views about nature being humankind's nemesis; about the wilderness being a strange, hazardous entity that needs taming.

However, concentrationary literature also hints at a much deeper and complex understanding of nature. In fact, animals such as the free -or caged-bird and the howling wolf become fraternizing symbols: inmates relate to animal suffering not only because of the physical treatment received, but also due to language and interpellation techniques used by the oppressor. In the corpus of analysis, these resources suggest the emergence of an interspecies empathy: apart from explicitly acknowledging animals' ability to feel pain or pleasure, authors attribute human qualities to nonhuman animals, therefore blurring the traditionally established limits between humankind and the rest of species. By claiming that some animals may be more human than certain human beings, they are reexamining and shaping a new concept of humanity, which is no longer grounded on biological and evolutional notions, but on the interspecies ability to sympathize with other hurting beings and, in turn, to feel pain oneself. This empathy stems from the endurance of shared ordeals, such as limitation of movement, forced work, malnutrition, and crowdedness. Furthermore, the memoirs also suggest other much less predictable, but far more profound, interspecies connections: issues like voicelessness and facelessness show in the testimonial accounts. Just like the Nazis tried to turn prisoners into undistinguishable beings, humans deny animals' uniqueness and individuality to subjugate them. The animal metaphor becomes a valuable resource to overcome in some way the ineffability inherent to all testimonies. I believe that, furthermore, these considerations reflect a real interspecies identification and sympathy, which goes beyond the merely representational and symbolical values of the metaphor as a literary trope. However, authors have to turn to the metaphor because, due to their sociocultural profiles, they do not have further HAS criticism strategies. 
This examination of concentrationary literature suggests that experiencing an exceptionally painful trauma often leads human victims to spontaneously turn to animal imaginary and empathize with animal suffering. Therefore, it is evident that human beings have the innate capability of sympathizing with abused animals and censoring their oppression. Examining these ideas through the lens of HAS, we should try to determine which conditions and psychological mechanisms operate universally, as it happens in the concentration camp, and account for the birth of an instinctive sense of interspecies conciliation and empathy. Once we clarify these circumstances, we will be able to apply our findings to our general societies. By doing so, we may succeed in raising deeper social awareness regarding animal oppression and take further, steady steps towards animal liberation.

\section{References}

Anderson, R. et al. (2016) "Orca Behavior and Subsequent Aggression Associated with Oceanarium Confinement", Animals, 6(8), 49.

Adorno, T. (1963) "Kulturkritik und Gesellschaft", in Tiedemann, R. (ed.), Prismen: Kulturkritik und Gesellschaft, München, DTV, 7-26.

Arendt, H. (1963) Eichmann in Jerusalem, New York, The Viking Press.

Aub, M. (1999) Manuscrito cuervo, Segorbe, fundación Max Aub.

Augustyn, P. (2018) "Animal Studies in the Language Sciences", Biosemiotics: A New Understanding of Life, 11, 121-138.

BitTon-JACKson, L. (1997) I Have Lived a Thousand Years, New York, Simon \& Schuster.

Bradshaw, G. A. et al. (2009) "Avian Affective Dysregulation: Psychiatric Models and Treatment for Parrots in Captivity", Proceedings of the Association of Avian Veterinarians, 28th Annual Conference, Minnesota. 
Сномsку, N. (2009) Cartesian Linguistics, Cambridge, Cambridge University Press.

Cole, L. (2016) Imperfect Creatures: Vermin, Literature, and the Sciences of Life, 1600-1740, Ann Arbor, University of Michigan Press.

Coetzee, J. M. (1999) The Lives of Animals, New Jersey, Princeton University Press.

Copeland, M. (2012) “Literary Animal Studies in 2012: Where We Are, Where We Are Going", Anthrozoos, 25, 91-105.

DrIx, S. (1994) Witness to Annihilation: Surviving the Holocaust, New Jersey, Brassey's.

FöGEN, T. (2014) "Animal Communication", in Campbell, G. L. (ed.), The Oxford Handbook of Animals in Classical Thought, Oxford, Oxford University Press, 1-18.

Geve, T. (1987) Guns and Barbed Wire: A Child Survives the Holocaust, Chicago, Academy Chicago Publishers.

Jacoвs, B. (1995) The Dentist of Auschwit:: A Memoir, Kentucky, The University of Kentucky Press.

Kogon, E. (1974) Der SS-Staat: Das System der deutschen Konzentrationslager, München, Kindler.

Lasker-Wallfisch, A. (2000) Inherit the Truth: A Memoir of Survival and the Holocaust, New York, Thomas Dunne Books.

Lengyel, O. (1995) Five Chimneys: A Woman Survivor's True Story of Auschwitz, Chicago, Academy Chicago Publishers.

LÉvinas, E. (1976) Difficult Freedom, Baltimore, Johns Hopkins University Press.

Levi, P. (1989) Los hundidos y los salvados, Barcelona, Muchnik.

Magyar-Isaacson, J. (1990) Seed of Sarah: Memoirs of a Survivor, Chicago, University of Illinois Press.

Parrau, A. (1995) Écrire les camps, Paris, Belin.

Peтó, A. et al. (eds.) (2015) Women and the Holocaust: New Perspectives and Challenges, Warszawa, Central European University Press.

Robin, K. \& Long, J. (2011) “Animal Metaphors and Metaphorizing Animals: An Integrated Literary, Cognitive, and Evo- 
lutionary Analysis of Making and Partaking of Stories", Evo Edu Outreach, 4, 52-63.

SAnfilippo, M. (2016) "Liana Millu e Charlotte Delbo: scrivere e riscrivere la memoria", Quaderns de Filologia. Estudis Literaris, 21, 173-189.

SAX, B. (2015) "Holocaust Images and Other Powerful Ambiguities in the Debates on Animal Experimentation: Further Thoughts", Anthrozoös, 6, 108-114.

Seligman, M. (1972) "Learned Helplessness", Annual Review of Medicine, 23, 407-414.

Seliner, E. C. (2019) Our Dog Red: A Small Token of Remembrance, Oregon, Resource Publications.

Singer, P. (1975) Animal Liberation: A New Ethics for Our Treatment of Animals, New York, HarperCollins.

Spiegel, M. (1996) The Dreaded Comparison: Human and Animal Slavery, New York, Mirror Books.

Spiegelman, A. (2003) Maus: A Survivor's Story. New York: Penguin.

Sztybel, D. (2006) "Can the Treatment of Animals Be Compared to the Holocaust?", Ethics and the Environment, 11(1), 97132.

Taszak, J. (2009) "Other/Otherness", in Kitchin, R. \& Thrift, N. (eds.), International Encyclopedia of Human Geography, Oxford, Elsevier Science, 3-7.

Tydor Baumel, J. (1998) Double Jeopardy: Gender and the Holocaust, London/New York, Routledge.

TryuK, M. (2010) “Interpreting in Nazi Concentration Camps during World War II", Interpreting, 12(2), 125-145.

Tuvel Bernstein, S. (1997) The Seamstress: A Memoir of Survival, New York, G. P. Putnam's Sons.

Waldau, P. (2013) Animal Studies: An Introduction, Oxford, Oxford University Press.

Webber, M. (2011) "Metaphorizing the Holocaust: The Ethics of Comparison", Images: The International Journal of European Film, Performing Arts and Audiovisual Communication, 8(15), 1-30. 
